\title{
PENGARUH ELECTRONIC WORD OF MOUTH DAN BRAND IMAGE TERHADAP PURCHASE INTENTION
}

\author{
Melinda Febriyanti Wongso ${ }^{1)}$ dan M. Rachman Mulyandi²) \\ 1)Universitas Matana, Tangerang \\ melinda.febriyanti@matanauniversity.ac.id \\ 2)Universitas Matana, Tangerang \\ rachman.mulyandi@matanauniversity.ac.id
}

\begin{abstract}
Abstrak
Seiring dengan perkembangan internet dan teknologi informasi, electronic word of mouth sudah menjadi hal yang penting dalam marketing. Penelitian ini bermaksud untuk mengulas pengaruh Electronic Word of Mouth dan Brand Image Terhadap Purchase Intention. Penelitian ini memerlukan studi kasus literature atau literature review dengan mempelajari sebanyak 10 jurnal dan hasilnya dipahami kemudian disimpulkan untuk mengetahui hubungan antara word of mouth dan brand image terhadap purchase intention.
\end{abstract}

Kata Kunci : Electronic Word of Mouth, Brand Image, Purchase Intention

\begin{abstract}
Along with the development of the internet and information technology, electronic word of mouth has become an important thing in marketing. This study intends to review the influence of Electronic Word of Mouth and Brand Image on Purchase Intention. This study requires a case study of literature or literature review by studying as many as 10 journals and the results are understood then concluded to find out the relationship between word of mouth and brand image on purchase intention
\end{abstract}

Keywords: Electronic Word of Mouth, Brand Image, Purchase Intention

\section{PENDAHULUAN}

\section{Latar Belakang}

Perkembangan teknologi membuat konsumen merasa ada di dunia baru di mana mereka dapat saling mempengaruhi satu sama lain maupun berkomunikasi. Semakin berkembang popularitas internet mengakibatkan e-WOM juga berkembang dari komunikasi satu arah menjadi komunikasi yang bersifat menyebar (Wibowo, 2015).

Henning-Thurau dan Walsh (dalam Utami, Tanujaya, Jokom, 2015) menyatakan internet menyediakan berbagai macam cara buat menerima keterangan yang berkaitan dengan produk atau jasa yang berasal dari konsumen lain. keterangan itu dianggap juga dengan Electronic Word of Mouth (e-WOM). Online review merupakan salah satu bentuk tatanan dari e-WOM.

Jansen (dalam Cahyono, Kusumawati, Kumadji, 2016), menyatakan bahwa walaupun memiliki kemiripan dengan WOM secara global, Electronic Word-of-Mouth (eWOM) bisa membagikan pilihan-pilihan baru dengan bermacam penjelasan secara rahasia, dan serta bisa melintasi batasan antara ruang dan area.

Dengan kelebihan yang dimiliki electronic word of mouth masyarakat cenderung memakai media tersebut untuk dijadikan dasar dari suatu pembelian karena keterangan yang bisa diperoleh dari electronic word of mouth lebih mudah utnuk diperoleh (Wibowo, 2015).

Menurut Steffes dan Burgee (2009), informasi yang didapatkan dari forum eWOM dapat mempengaruhi purchase intention dibandingkan dengan berbicara kepada teman-teman secara pribadi (WOM). Semakin tinggi e-WOM yang dilakukan oleh perusahaan kepada konsumen, maka akan menghasilkan minat beli yang tinggi juga (Chevalier \&amp; Mayzlin, 2006).

Brand Image berpotensi melambangkan hal penting yang dapat membedakan produk dengan pesaing. Menurut Kotler dan Keller (2012) citra merek merupakan pemahaman dan kepercayaan yang dipegang konsumen, sebagaimana tercermin dalam perhimpunan yang tercantum dalam benak konsumen. 
Brand image (citra merek) merupakan semacam gambar atau kesan yang dilahirkan oleh sebuah merek pada pikiran pelanggan. Penempatan citra merek dibenak konsumen wajib dilaksanakan secara berkepanjangan agar citra merek yang tercipta selalu kuat dan bisa diterima secara baik. Saat suatu merek mempunyai citra yang stabil dan baik dipikiran konsumen bahwa merek itu akan selalu dipikirkan dan adanya jalan kepada pelanggan untuk memesan merek yang berhubungan sangat besar.

Minat beli konsumen selalu tertutup dalam setiap individu yang mana tak ada seorang pun yang bisa mengetahui apa yang dibutuhkan dan digemari konsumen.

Nulufi dan Murwatiningsih (dalam Shahnaz \&amp; Wahyono, 2016) pelanggan yang telah mempunyai sikap baik pada sebuah produk atau merek, hendak mendatangkan minat pembelian kepada produk dan merek tersebut.

Niat beli merupakan kesanggupan konsumen untuk membeli produk tertentu dalam kondisi tertentu. niat beli biasanya terikat dengan perilaku, persepsi dan sikap pelanggan.

Shah, Syed Saad Hussain (dalam Manurang \& Mawardi, 2018) menunjukkan bahwa niat beli merupakan golongan pengumpulan keputusan mengenai alasan megapa pelanggan lebih memilih membeli merek tertentu.

Berdasarkan fakta diatas bisa dirumuskan beberapa pertanyaan yang hendak dijawab dengan penelitian ini, sebagai berikut.

1. Mencari tahu apakah ada dammpak yang terjadi antara electronic word of mouth dan purchase intention.

2. Mencari tahu apakah ada dapak yang terjadi antara brand image dan purchase intention.

3. Mencari tahu apakah ada dampak yang terjadi antara electronic word of mouth dan brand image kepada purchase intention.

\section{TINJAUAN PUSTAKA}

\section{e-WOM}

Henning-Thurau et al., (dalam Hastina, 2017) Electronic Word of Mouth merupakan penjelasan buruk atau baik yang dilakukan oleh pelanggan nyata, potensial atau pelanggan sebelumnya tentang suatu produk atau perusahaan dimana keterangan ini ada bagi orang-orang ataupun institusi dari via jaringan media.

Chatterjee (dalam Jalilvand dan Samiei, 2012), penggunakan internet juga media sosial merupakan hal yang paling berarti lantaran word of mouth tidak hanya dilakukan secara perorangan tetapi dapat melalui internet yang diucap oleh electronic word of mouth (e-WOM).

Berdasarkan teori diatas, dapat disimpulkan bahwa e-WOM merupakan sebuah penjelasan baik positif maupun negatif yang dibuat oleh konsumen tetang sebuah produk dan e-WOM dapat dilaksanakan melewati jaringan media

\section{Brand Image}

Menurut Tjiptono (2015), citra merek dapat disimpulkan menjadi sebuah penjelasan asosiasi dan kepercayaan konsumen atas merek tertentu. Citra merek (Brand Image) merupakan penglihatan dan kepercayaan yang digenggam oleh pelanggan, seperti yang tergambar di gambaran atau di ingatan pelanggan.

Kotler dan Armstrong (2014), mengemukakan bahwa citra merek merupakan "The set of believe held about aparticular brand is known as brand image". Jadi dapat disimpulkan bahwa citra merek merupakansebuah kepercayaan yang dimiliki konsumen tentang suatu merek tertentu.

Berdasarkan teori diatas dapat disimpulkan bahwa brand image merupakan kepercayaan yang dipercaya konsumen akan suatu merek.

\section{Minat Beli}

Kotler dan Keller (dalam Hermawan, 2017) minat beli pelanggan merupakan suatu sikap pelanggan dimana pelanggan tersebut memiliki ambisi dalam membeli atau menentukan sebuah produk, berlandaskan pengetahuan dalam memilih, memakai dan menghabiskan atau bahkan menginginkan sebuah produk.

Menurut Simamora (2011), minat beli adalah sebuah kemauan pribadi untuk memiliki suatu barang atau objek tertentu. 
Berdasarkan teori diatas, dapat diartikan bahwa minat beli adalah sebuah sifat pelanggan dengan dorongan dan kemauan untuk mendapatkan barang atau objek tertentu.

Pradipta dan Purwanto (dalam Manuarang \& Mawardi, 2018) menjabarkan proses pengukuran minat beli menggunakan model AIDA (Awareness, Interest, Desire, dan Action). Berikut penjelasannya.

a. Awareness (kesadaran)

Proses dimana perusahaan memberikan informasi dasar akan sebuah produk yang membuat para konsumen merasa sadar atas adanya produk atau jasa tersebut, baik menggunakan promosi berupa media cetak, radio, televisi, ataupun internet. Kesadaran atau awareness merupakan proses awal dalam komunikasi perusahaan dengan konsumen.

b. Interest (ketertarikan)

Perusahaan mengeluarkan iklan atas produk atau jasanya untuk menarik konsumen. Proses ini dimana konsumen telah berhasil tertarik akan produk tersebut. Kemudian konsumen diberikan informasi tentang produk, dibujuk dan diberikan alasan yang tepat Apa alasan pelanggan harus memesan dan memiliki produk yang ditawarkan perusahaan. Ketertarikan atau interest merupakan prioritas perusahaan.

c. Desire (keinginan)

Proses dimana

perusahaan memberikan keterangan yang berisi tentang produk atau jasanya secara rinci, seperti keunggulan dan kehebatannya. Perusahaan juga memberikan penawaran yang menarik sehingga konsumen tidak dapat menolak tawaran tersebut dan merasa ingin membeli atau memiliki produk tersebut.

d. Action (tindakan)

Proses dimana adanya kemauan yang kuat dari konsumen sehingga menimbulkan tindakan yang terjadi untuk melakukan pembelian atau transaksi untuk memenuhi keinginannya untuk produk atau jasa tersebut yang ditawarkan oleh perusahaan.

\section{METODOLOGI PENELITIAN}

Penelitian menggunakan penelitian kualitatif, karena penelitian kualitatif memiliki kelebihan antara lain memberikan informasi yang lebih kompleks dan mendalam mengenai topik yang diteliti dalam memahami sikap, persepsi, emosi, keyakinan, motif, dan perilaku obyek (Yuliansyah dan Bui, 2013).

Analisis data dalam penelitian ini menggunakan studi literature dengan mempelajari 10 jurnal yang terkait dengan electronic word of mouth, brand image, dan purchase intention. Data yang diterima akan dianalisis dengan melihat pada cara analisis sampel kualitatif yaitu pengecilan data, sajian data dan penarikan keputusan (Yuliansyah, Hakim \& Suryani, 2015). Hasil dari berbagai literature yang peneliti amati digunakan untuk mengetahui hubungan antara electronic word of mouth dan brand image kepada purchase intention.

\section{PEMBAHASAN}

Penelitian yang dilakukan oleh Arif Wibowo (2015), yang berjudul Pengaruh Electronic Word Of Mouth dan Brand Image terhadap Purchase Intention pada Konsumen Smartphone Samsung yang Berbasis Android. Penelitian ini menjelaskan bagaimana pengaruh electronic word of mouth dan brand image terhadap purchase intention smartphone Samsung. Penelitian ini memakai cara pendekatan yang terukur. Cara pengumpulan sampel yang digunakan merupakan Non-Probability Sampling serta mengambil 100 mahasiswa yang memakai smartphone Samsung dengan berbasis Android. Metode pengumpulan informasi dilaksanakan dengan cara mengedarkan kuesioner self administered survey. Hasil penelitiannya adalah variabel electronic word of mouth berdampak positif kepada variable purchase intention dan brand image berdampak baik terhadap purchase intention.

Penelitian yang dilaksanakan oleh Cahyono, Kusumawati, dan Kumadji (2016), yang berjudul ulasan faktor-faktor pembentuk electronic word of mouth (e-WOM) dan pengaruhnya terhadap minat beli (Survei pada Followers Akun Instagram @saboten_shokudo). Penelitian ini memakai metode pendekatan kuantitatif (explanatory research). Teknik pengumpulan sampel menggunakan teknik Purposive Sampling dengan responden yaitu followers 
@saboten_shokudo yang berusia minimal 17 tahun dan sudah mengetahui atau menyetujui keterangan mengenai restoran Saboten Shokudo dari instagram. Pengumpulan data untuk penelitian ini yaitu untuk mengedarkan kuesioner secara tidak langsung serta memakai skala Likert. ulasan deskriptif, ulasan faktor dan ulasan regresi linier berganda adalah cara yang dipakai untuk penelitian ini. Hasil penelitiannya adalah terdapat lima buah faktor yang membentuk Electronic Word of Mouth (eWOM), yaitu: Platform Assistance, Expressing Positive Feelings, Economic Incentives, Helping the Company, dan Concern for Others. Elemen Concern for Others mempunyai dampak dominan kepada Minat Beli.

Penelitian yang dilaksanakan oleh Riyanti, Puspitasari, dan Ariningsih (2015), yang berjudul Pengaruh Electronic Word of Mouth dan Brand Image kepada Purchase Intention (Studi pada Peminat Shampoo Pantene di Purworejo). Cara pengumpulan sampel menggunakan cara Purposive Sampling serta mengambil 100 responden. Pengumpulan informasi untuk penelitian ini mengedarkan kuesioner untuk skala Likert yang sudah diuji coba dan telah melaksanakan permintaan kebenaran dan perbaikan. Regresi linier bertambah merupakan cara ulasan data yang dipakai dalam penelitian ini. Hasil penelitiannya adalah electronic word of mouth dan brand image secara universal berdampak baik dan relevan kepada purchase intention pada peminat Shampoo Pantene di Purworejo.

Penelitian yang dilakukan oleh David Saputra (2016), yang berjudul Pengaruh Electronic Word Of Mouth dan Brand Image kepada Purchase Intention Smartphone Merek Apple Iphone di Bandar Lampung. Penelitian ini menguraikan bagaimana pengaruh electronic word of mouth dan brand image kepada purchase intention smartphone Apple iPhone. Penelitian ini memakai cara pendekatan kuantitatif dengan mengedarkan kuesioner kepada 150 responden. Cara pengumpulan sampel untuk penelitian ini memakai cara Non-Probability Sampling dengan cara Snowball Sampling. Pengumpulan informasi yang dipakai untuk penelitian ini yaitu Structural Equation Modeling (SEM) untuk software AMOS 18. Hasil penelitiannya adalah electronic word of mouth (e-WOM) bukan berdampak secara relevan kepada purchase intention smartphone Apple iPhone, electronic word of mouth (e-WOM) berdampak secara relevan kepada brand image atas smartphone Apple iPhone, brand image berdampak secara signifikan kepada purchase intention.

Penelitian yang dilakukan oleh Laksmi dan Oktafani (2016), yang berjudul Pengaruh Electronic Word of Mouth (e-WOM) kepada Minat Beli Followers Instagram Pada Warunk

Upnormal. Teknik Sampling yang dipakai merupakan nonprobality sampling dengan metode pengumpulan sampel purposive sampling. Kuesioner diberikan kepada 400 responden. Teknik analisis data yang dipakai merupakan analisi regresi linier sederhana. hasil penelitiannya adalah electronic word of mouth tidak berdampak relevan kepada purchase intention.

Penelitian yang dilakukan oleh Wardiyastuti (2017), yang berjudul Pengaruh Electronic Word of Mouth kepada Minat Beli Konsumen Melalui Brand Image (studi pada followers instagram Wedangan Radjiman sebagai calon konsumen. penelitian ini memakai cara pendekatan kuantitatif dengan menyebarkan kuesioner kepada 200 responden yang belum sempat berkunjung ke Wedangan Radjiman. Cara pemungutan model yang dipakai untuk penelitian ini merupakan purposive sampling. Cara pengumpulan informasi untuk penelitian ini memakai skala likert yaitu: memberikan penilaian dari 1 yang artinya sangat tidak setuju (STS) hingga 5 yang artinya sangat setuju (SS). Hasil dari penelitian itu menyatakan bahwa electronic word of mouth dan brand image mempunyai dampak yang baik kepada minat beli dari konsumen Wedangan Radjiman.

Semuel dan Lianto (2014) melakukan penelitian dengan judul Analisis e-WOM, Brand Image, Brand Trust dan Minat Beli Produk Smartphone di Surabaya. Penelitian ini memakai purposive sampling yang dilakukan kepada 250 konsumen yan menggunakan program SPSS versi 13 dan SmartPLS versi 2.00. Hasil dari penelitian ini adalah e-WOM memiliki pengaruh langsung kepada brand image dan minat beli, e-WOM memberikan pengaruh yang positif kepada brand image dan memberikan dampak yang baik juga terhadap minat beli. 
Penelitian yang dilakukan oleh Suyoga dan Santika (2018), yang berjudul Peran Brand Image dalam perantaraan dampak Electronic Word of Mouth kepada Niat Beli. Penelitian ini memakai cara analisa sampel dengan mengedarkan kuesioner kepada 100 responden. Cara pengumpulan sampel yang dilakukan untuk penelitian ini merupakan non-probability sampling. Analisis jalur (path analysis) merupakan cara penjabaran yang dipakai dalam penelitian ini. Hasil yang didapat dari penelitian ini adalah electronic word of mouth memiliki dampak yang bersifat positif dan juga signifikan akan niat beli konsumen. Begitu juga dengan brand image yang memiliki dampak baik kepada niat beli pelanggan.

Gadhafi dan Ilfitriah (2015), melaksanakan penelitian yang berjudul The Influence of Electronic Word of Mouth on Purchase Intention are Mediated by Brand Image on Acer Laptop Products in Surabaya. Populasi dari penelitian ini merupakan pengguna laptop Acer di Surabaya. Penelitian ini menggunakan purposive sampling untuk sebagai cara mengumpulkan sampel dengan mengedarkan kuesioner kepada 100 responden. Untuk penelitian ini dua cara ulasan yaitu ulasan deskriptif (descriptive analysis) dan ulasan jalur (path analysis) menggunakan media bantu SPSS 17. Hasil yang didapatkan dari penelitian memakai ulasan jalur (path analysis) adalah electronic word of mouth dan brand image memiliki dampak yang baik dan signifikan kepada minat beli pelanggan laptop Acer di Surabaya.

Darmawan dan Nurcaya (2018), melaksanakan penelitian yang berjudul Membangun Niat Beli Iphone Melalui e-WOM dan Brand Image. Penduduk kota Denpasar Bali yang memiliki niat untuk membeli iPhone menjadi populasi untuk penelitian ini. Cara pengumpulan sampel untuk penelitian ini yaitu menggunakan purposive sampling dan mengumpulkan 110 responden. Dua cara penjabaran, yaitu penjabaran jalur (path analysis) dan uji sobel yang dilakukan dalam penelitian ini. Keputusan dari penelitian ini merupakan adanya hubungan yang bersifat baik dan penting antara electronic word of mouth dengan brand image, electronic word of mouth dengan niat beli, dan brand image dengan niat beli. Berdasarkan hasil diatas, maka bisa diartikan bahwa e-WOM yang bersifat positif bisa meningkatkan brand image produk iPhone, juga sanggup meningkatkan niat beli konsumen akan produk iPhone.

\section{KESIMPULAN}

Menurut hasil dari penelitian menggunakan studi literature dapat diartikan bahwa adanya hubungan yang signifikan antara electronic word of mouth dan brand image kepada purchase intention. Hal ini dapat diartikan sebagai seiring dengan meningkatnya level keterkaitan terhadap electronic word of mouth dan brand image, maka purchase intention pada sebuah merk yang berhubungan juga akan menjadi semakin kuat.

Adapun dari studi literature yang peneliti lakukan, objek penelitian tidak terlalu berpengaruh dalam perubahan hasil pengaruh dari setiap penelitian, sehingga baik produk ataupun jasa yang telah mengalami electronic word of mouth dan brand image maka akan selalu tercipta purchase intention pada konsumen untuk melakukan pembelian.

\section{DAFTAR PUSTAKA}

Aditya, A., \& Oktafani, F. (2016). Pengaruh Electronic Word of Mouth (eWOM) Terhadap Minat Beli Followers Instagram Pada Warunk Upnormal.

Bilson Simamora, 2011, Riset Pemasaran, Cetakan Pertama, Jakarta: Gramedia Pustaka Utama.

Cahyono, F. D., Kusumawati, A., \& Kumadji, S. (2016). Analisis Faktor-Faktor Pembentuk Electronic-Word-of-Mouth (eWOM) dan Pengaruhnya Terhadap Minat Beli (Survei pada Followers Akun Instagram @saboten_shokudo).

Chevalier, J. A. \& Mayzlin, D. (2006), "The Effect of Word of Mouth on Sales: Online Book Reviews", Journal of Marketing Research, Vol. 43 No. 3 pp. 345354

Darmawan, R., \& Nurcaya, I. N. (2018). Membangun Niat Beli Iphone Melalui eWOM dan Brand Image.

Eliasari, P. R., \& Sukaatmadja, I. P. (2017). Pengaruh Brand Awareness Terhadap Purchase Intention di Mediasi Oleh Percived Quality dan Brand Loyalty.

Erin M. Steffes, Lawrence E. Burgee, (2009) "Social ties and online word of mouth", 
Internet Research, Vol. 19 Issue: 1, pp.4259,

Gadhafi, M., \& Ilfitriah, A. M. (2015). The Influence of Electronic Word of Mouth on Purchase Intention are Mediated by Brand Image on Acer Laptop Products in Surabaya.

Hastina, P. (2017). Pengaruh Dimensi Electronic Word of Mouth (eWOM) di Media Sosial Instagram Terhadap Keputusan Pembelian Pada Café Grannysnest di Bandar Lampung.

Hermawan, A. (2017). Pengaruh Word of Mouth Terhadap Minat Berkunjung Pemustaka Pada Perpustakaan Daerah Salatiga.

Jalilvand, M.R. dan Samiei, N. (2012),"The Effect of Electronic Word of Mouth on Brand Image and Purchase Intention", Marketing Intellegence \& Planning, Vol. 30, No.4, pp. 460-476

Kotler, dan Keller. (2012). Manajemen Pemasaran. Edisi 12. Jakarta: Erlangga

Kotler, Philip. \& Gary Armstrong. 2014. Principle Of Marketing, 15th edition. New Jersey: Pearson Prentice Hall

Laksmi, A. A., \& Oktafani, F. (2016). Pengaruh Electronic Word of Mouth (eWOM) Terhadap Minat Beli Followers Instagram pada Warunk Upnormal.

Manuarang, R. N., \& Mawardi, M. K. (2018). Pengaruh Product Knowledge Terhadap Purchase Intention (Survei pada Pengunjung Toko Buku UB Press, Kota Malang) .

Riyanti, A., Puspitasari, I., \& Ariningsih, E. P. (2017). Pengaruh Electronic Word of Mouth dan Brand Image terhadap Purchase Intention (Studi pada Peminat Shampoo Pantene di Purworejo).

Saputra, D. (2016). Pengaruh Electronic Word of Mouth dan Brand Image Terhadap Purchase Intention Smartphone Merek Apple Iphone di Bandar Lampung.

Semuel, H., \& Lianto, A. S. (2014). Analisis e-WOM, Brand Image, Brand Trust, dan Minat Beli Produk Smartphone di Surabaya.

Shahnaz, N. B., \& Wahyono. (2016). Faktor yang Mempengaruhi Minat Beli Konsumen di Toko Online.

Suyoga, I. B., \& Santika, I. W. (2018). Peran Brand Image dalam Memediasi Pengaruh Electronic Word of Mouth Terhadap Niat Beli.
Tjiptono, Fandy, 2015 . Brand Management \& Strategy. Yogyakarta : Andi

Utami, V. K., Tanujaya, D., \& Jokom, R. (2015). Analisa Fakor yang Penting dari Dimensi World of Mouth (eWOM) Bagi Konsumen Dalam Memilih Hotel di Situs Online Travel Agent (OTA).

Wardiyastuti, D. (2017). Pengaruh Electronic Word of Mouth Terhadap Minat Beli Konsumen Melalui Brand Image (Studi Pada Followers Instagram Wedangan Radjiman Sebagai Calon Konsumen).

Wibowo, A. (2015). Pengaruh Elektronik Word of Mouth dan Brand Image Terhadap Purchase Intention pada Konsumen Smartphone Samsung yang Berbasis Android.

Yudianti, D., \& Indarti, S. (2016). Analisis Komparatif Ekspektasi Pelanggan, Citra Toko, dan Kepuasan Pelanggan pada Toko Spesial di Pekan Baru. 